\title{
A ÉTICA ECONÔMICA DO BUDISMO PRIMITIVO.
}

RICARDO MARIO GONCALVES

Disciplina: História do Extremo-Oriente.

\section{INTRODUÇÃO.}

Nas primeiras décadas do nosso século, os estudos de Max Weber, E. Troeltsch, R. H. Tawney, Werner Sombart e outros chamaram a atenção para as relações existentes entre o pensamento religioso e a vida econômica. Preocupados com o problema da formação do $\mathrm{Ca}$ pitalismo, investigaram eles as prováveis motivações religiosas que interferiram no processo de desenvolvimento do chamado "espírito do Capitalismo", buscando-as, quer no Protestantismo, no caso de Weber, Troeltsch e Tawney, quer no Judaismo, no caso de Sombart. Meditando sobre esses estudos, muitas vezes nos perguntamos se o mesmo raciocínio empregado por esses pesquisadores não poderia ser aplicado tambem às outras tradições religiosas que não a judaico-cristã, ao se estudar o processo de modernização ocorrido em regiōes fora da civilização ocidental. De certa forma, tais indagações representam um prosseguimento das indagações do próprio Max Weber que, em seus trabalhos de sociologia religiosa, não se limitou a perscrutar as relações entre o Capitalismo Ocidental e a tradição cristã, procurando, através de um minucioso estudo das tradições religiosas e filosóficas da China e da India, descobrir em que medida as mesmas atuaram como um elemento desencorajador do desenvolvimento do Capitalismo nessas culturas. Segुundo Weber, em determinadas fases de sua história, essas civilizações experimentaram condições favoráveis para o desenvolvimento do Capitalismo, como por exemplo o incremento do grande comércio interno e externo, ou a importância e o prestígio de que muitas vezes usufruiram os elementos dedicados à atividade mercantil. Entretanto, apesar dessas condiçōes favoráveis não houve o desenvolvimento do Capitalismo obstado pelo conservadorismo próprio dos letrados confucionistas, no caso chinês, e pelos tabus e restrições próprias da sociedade de castas mais o pre- 
domínio do ascetismo monástico, no caso indiano. A história contemporânea da China e da India confirmam as observações de Max Weber, na medida em que só agora, após um século de dominação semi-colonial, a China começa a se modernizar por vias totalmente diferentes do sistema capitalista, e, no caso da India, as tradiçōes hindus continuam a representar um poderoso entrave aos esforços pela modernização. O processo de modernização dos paises do Sudeste Asiático, de civilização influenciada pelas tradições indianas e chinesas, tambem se revela extremamente lento e penoso.

Existe porem na Ásia Oriental uma única e importante exceção, um país que, em fins do século XIX conseguiu, em poucas décadas, neutralizar a pressão imperialista das potências ocidentais e modernizar suas estruturas sócio-econômicas segundo a via capitalista, revelando-se em breve como um rival e competidor das nações que the serviram de modelo: o Japão, país cuja civilização tradicional era tambem herdeira da cultura chinesa, com importantes, contribuições da cultura indiana. O estudo do processo de modernização do Japão e de suas causas tem se revelado um dos mais fascinantes temas da historiografia contemporânea .

A primeira atitude tomada pelos estudiosos do problema, tanto os do Ocidente como os do próprio Japão, foi de explicar o processo de modernização como produto exclusivo do impacto da cultura ocidental sobre a civilização nipônica e pelo ardor com que os japoneses souberam se desembaraçar de suas velhas tradições para ingressar na via de ocidentalização e da industrialização. Para esses primeiros pesquisadores, bem como para os próprios líderes japoneses, a tradição japonesa não era senão um entrave à modernização, de que o Japão soube habilmente se libertar. O historiador mais representativo dessa primeira corrente é Edward H. Norman (Japan's Emergence as a Modern State, New York, 1940), cujo pensamento exerceu uma enorme influência sobre os pesquisadores do mundo ocidental e do próprio Japão. Entretanto, não podemos explicar a modernização japonesa unicamente pelo impacto da civilização ocidental, pois outras áreas da Ásia Oriental sofreram igualmente esse impacto, sem que se verificasse nenhum processo semelhante ao nipônico. E necessário portanto verificar quais foram as condições existentes na civilização tradicional do Japão que estimularam o japonês a reagir prontamente frente ao desafio da pressão ocidental através de um engajamento consciente na tarefa de modernizar o país seguindo o modelo capitalista ocidental. Assim, os pesquisadores mais recentes, tanto no Japão como no Ocidente, voltam-se para o estudo das instituições, da conjuntura sócio-econômica, da cultura e da mentalidade do Japão pré-industrial, buscando as condições que estimularam a adesão do japonês ao capitalismo ocidental. E nessa linha que trabalham os novos japonologistas como Edwin Reischawer, John Witney Hall, Ma- 
rius B. Jansen, Conrad Totman, Harold Bolitho, Susan Hanley, William Hauser e Robert N. Bellah. Especialistas japoneses como Ryoen Minamoto, Hajime Nakamura, Yushô Miyasaka e Ryukichi Mori tambem tem se preocupado, numa linha de raciocínio inspirada em Max Weber, para verificar em que medida as escolas tradicionais de pensamento como o Budismo e o Confucionismo contribuiram para criar no povo japonês uma mentalidade favoravel ao engajamento no processo de modernização segundo a via capitalista .

E nossa intenção desenvolver um estudo sobre a tradição budista japonesa, concentrando-nos principalmente nos autores da última fase da sociedade feudal nipônica (Período Tókugawa, 1600-1868), a fim de verificar até que ponto a mesma favoreceu a criação de uma mentalidade racionalizante e valorizadora da atividade econômica, favoravel à assimilação do sistema capitalista. Estaremos dessa forma aprofundando a linha de pesquisa inaugurada pelo japonologista americano Robert $\mathrm{N}$. Bellah, que em seu trabalho já clássico Tokugawa Religion - The Values of Pre-Industrial Japan (Glencoe, 1957) que demonstrou a existência de elementos racionalizantes e modernizantes no pensamento religioso do Período Tokugawa. Bellah concentrou sua atenção no Shingaku, escola ético-religiosa sincrética que divulgava entre os comerciantes uma doutrina baseada em princípios budistas e confucionistas, elaborada por Ishida Baigan (1685-1744). Nossas investigações procurarão demonstrar que tais elementos modernizantes e racionalizantes não são monopólio das novas escolas surgidas durante o Período Tokugawa, que eles existem, pelo menos no que toca o Budismo, em escolas tradicionais de grande antiguidade. Podemos rastrear a origem desses elementos no próprio Budismo Original Indiano, o que procuramos fazer no presente artigo.

\section{I. - BUDISMO MONĀSTICO E BUDISMO LAICO.}

A primcira impressão que o Ocidental tem do Budismo quando procura conhece-lo através dos manuais de uso corrente, escritos por orientalistas europeus, é de que o mesmo é uma doutrina baseada num ascetimo monástico radical, que desencoraja totalmente qualquer preocupação com a atividade econômica e com a riqueza. Essa impressão se baseia em grande parte nas observações feitas nas comunidades budistas dos paises do Sudeste Asiático e nos estudos dos textos canônicos utilizados pelas mesmas. No Sudeste Asiático ainda hoje os monges se distinguem do resto da população pelos seus tradicionais mantos amarelos e por suas tigelas de esmolas, únicos bens materiais que as regras monásticas lhes permitem possuir. Sendo-lhes vedada a participação em qualquer atividade produtiva, vivem exclu- 
sivamente de doações de alimentos oferecidas pelos fieis leigos. Pela manhã percorrem eles as ruas das cidades e aldeias portando suas tigelas de esmolas nas quais os fieis despejam suas dádivas em alimentos. Antes do meio dia já estão de volta a seus monastérios, para que possam tomar a sua refeição diurna que, segundo as regras monásticas, tem de ser iniciada antes das doze horas. Nenhum alimento sólido poderá ser ingerido depois dessa hora. $\mathrm{O}$ resto do dia é dedicado à pregação ou à meditação.

Nenhum quadro contrasta de modo mais violento com esse do que aquele que se descortina ante os olhos do observador das comunidades budistas do Japão contemporâneo. Primeiramente, é bastante dificil distinguir um monge de um leigo, uma vez que a maior parte dos monges só enverga seus trajes monásticos por ocasião dos rituais. Casam-se e vivem normalmente em família como qualquer leigo, ao contrário de seus colegas da Ásia do Sudeste, que guardam o mais estrito celibato. Muitos atuam no magistério, no funcionalismo público, no comércio, na indústria e até mesmo na política, enquanto que os monges da Ásia do Sudeste nem sequer podem tocar em dinheiro. Vemos pois que a palavra "Budismo" abarca realidades bem diferentes, conforme a região considerada e que a maior parte das conceituações simplistas que campeiam os manuais de uso corrente no mundo ocidental incorrem no erro de tomar a parte pelo todo.

Um estudo minucioso e amplo dos textos mais antigos do Canon Budista, conservados nas versões em língua Pali utilizadas pelos budistas da Ásia do Sudeste e nas versões em chinês usadas pelos budistas da Ásia Oriental nos mostra que o Budismo Primitivo, isto é, o Budismo do fundador Siddhartha Gautama e das primeiras gerações de discípulos, se caracterizava por duas tradições paralelas, uma monástica e outra laica. O código de conduta pregado aos leigos, como veremos em relação à atitude frente aos problemas econômicos, era totalmente diferente do pregado aos monges. No Budismo da Ásia do Sudeste triunfou a tradição do ascetismo monástico, mas no Japão, paralelamente a esta desenvolveu-se a tradição laica, que acabou prevelecendo no Japão contemporâneo, acabando por influenciar e absorver a própria tradição monástica. Já nos primórdios da história japonesa o Príncipe Regente Shôtoku (574-622) se apresentava como apóstolo do budismo laico, realizando pregações e escrevendo comentários de textos budistas, mas sem se ingressar na vida monástica e sem se afastar de sua atividade de estadista. No século XIII surgiu com Shinran (1173-1262) a primeira comunidade budista cujos bonzos proclamaram publicamente a renúncia ao ascetismo monástico, abandonando as regras e assumindo as responsabilidades da vida familiar. No Período Tokugawa, mesmo fora do movimento de Shinran, inúmeros foram os instrutores que preconizaram um bu- 
dismo laico, como Suzuki Shosan (1579-1655), Jiun (1718-1804), etc. A partir de 1868, com a Restauração Meiji e o início do processo de modernização um edito governamental liberou os bonzos do dever de obediência às regras monásticas e a maior parte dos mesmos passou a seguir o exemplo da comunidade fundada por Shinran.

Passemos agora ao estudo das raizes indianas dessa tradição laica e da atitude da mesma frente aos problemas econômicos.

\section{II. - A RACIONALIDADE NO BUDISMO PRIMITIVO.}

Antes de abordar especificamente o problema das prescrições éticas relativas à economia contidas na tradição laica do Budismo Primitivo, é necessário tratar do carater racional do mesmo. Com efeito, se, como diz Max Weber, a racionalidade é uma das principais condições para a modernização e para a organização de uma economia capitalista (ou socialista), encontramos já no Budismo Primitivo as raizes de uma importante tradição racionalista.

O Budismo, desde seus primórdios, rejeitava a revelação e a autoridade dos antigos mestres ou textos sagrados como fontes do conhecimento da verdade. Para o Budismo, as fontes válidas para o conhecimento estão na experiência pessoal (intuição mística inclusive) e no uso crítico da razão (1). Essa atitude está bem expressa no bem conhecido Kalama Sutta (Sermão aos Kalamas):

Um dia o Buda, que percorria a região dos príncipes de Kalama, foi interrogado por eles:

- Senhor, os Brâmanes e os líderes sectários vêm até nós e cada um deles afirma solenemente que só aquilo que ele ensina é verdadeiro e que tudo o mais não passa de erro. Isso nos coloca em estado de dúvida, não sabemos que doutrina aceitar.

O Buda respondeu que a dúvida nasce da natureza das coisas e aconselhou-os a não crer em nada baseando-se nas palavras de outrem:

- Não acrediteis em nada confiando nas tradições, mesmo que estas sejam veneradas desde muitas gerações e em muitos lugares. Não acrediteis numa coisa só porque muitos falam dela. Não confieis na autoridade dos sábios dos antigos tempos. Não acrediteis naquilo que vós mesmos imaginastes, pensando que um Deus vos tenha inspirado. Não acrediteis em nada confiando ape-

(1). - Sobre as fontes do conhecimento da Verdade no Budismo vide o importante estudo de JAYATILLEKE (K. N.), Early Buddhist Theory of Knowledge, London, George Allen \& Unwin Ltd., 1963. 
nas na autoridade de vossos mestres ou sacerdotes. Após um exame, acreditai naquilo que vós mesmos tiverdes experimentado e reconhecido como razoavel e como benéfico para vós mesmos e para os demais (2).

O Budismo Primitivo desencorajava o apego às superstições e às práticas adivinhatórias:

Meus discípulos não devem praticar as artes mágicas do Atharva Veda, a oniromância, a observação de presságios, a astrologia e a adivinhação através das vozes dos pássaros e dos animais.

\section{(Suttanipata) (3).}

Na tradição judaico-cristã os mandamentos e preceitos são apresentados como fundamentados exclusivamente na autoridade divina, não são acompanhados por justificativas de natureza racional:

E Moisés subiu para ir falar a Deus e o Senhor o chamou do monte e disse: Dirás estas coisas à casa de Jacó, e anunciarás aos filhos de Israel: Vós mesmos vistes o que eu fiz aos Egípcios, de que modo vos trouxe sobre asas de águia, e vos tomei para mim. Se, portanto, ouvirdes a minha voz, e observardes a minha aliança, sereis para mim a porção escolhida dentre todos os povos; porque toda a terra é minha. E sereis para mim um reino sacerdotal, e uma nação santa. Estas são as palavras que dirás aos filhos de Israel.

(Exodo XIX: 3-6).

E agora, ó Israel, ouve os preceitos e as determinações que eu te ensino, para que, observando-os, vivas, e entres na posse da terra, que o Senhor Deus de vossos pais vos há de dar. Não acrescentareis, nem tirareis nada à palavra que vos digo; guardai os mandamentos do Senhor vosso Deus, que eu vos intimo.

(Deuteronômio IV: 1,2).

$\mathrm{Na}$ tradição budista, porem, embora as motivações e sanções de natureza sobrenatural não estejam totalmente ausentes (promete-se um renascimento feliz ao cumpridor dos preceitos éticos e ameaça-se com uma existência futura penosa o desobediente), o que predomina é a justificação por meio de argumentos racionais da conveniência de

(2). - Citado por DAVID-NEEL (Alexandra), Le Bouddhisme, ses doctrines et ses Méthodes, Paris, Plon, 1936, p. 105, 106.

(3). - Citado por NAKAMURA (Hajime), Butten (Textos Budistas) 2 v., Tokyo, Chikuma, $1966,1^{9}$ v. p. 41. 
se observarem os preceitos e regras. Assim, o texto denominado Singalavada Suttanta, um dos principais repositórios dos preceitos éticos para leigos, justifica da seguinte maneira a necessidade do homem se abster da bebida e do jogo:

Se o homem se aplica à bebida e a outras causas da indolência, ocorrem os seguintes seis males:

1). - ele tem prejuizo financeiro;

2). - ele passa a discutir muito;

3). - ele se transforma num receptáculo de doenças;

4). - ele adquire má fama;

5). - ele se descobre vergonhosamente em público;

6). - ele tem diminuidas suas faculdades intelectuais.

Se o homem se vicia no jogo e em outras causas de vadiagem, ocorrem os seguintes seis males:

1). - ele desperta a animosidade de seus parceiros, se ganha;

2). - ele se entristece, se perde;

3). - ele tem prejuizo financeiro;

4). - se ele comparece ao tribunal, sua palavra não é mais digna de crédito;

5). - ele é desprezado por seus colegas e amigos;

6). - ele é repelido por aqueles que iriam providenciar seu casamento, pois o jogador é considerado indigno de ter uma esposa.

(Digha-Nikaya XXXI - Singalovada Suttanta 8, 11) (4).

Não se vê aí nenhuma menção de fatores de natureza sobrenatural, apenas se apela para a razão e para o bom senso do leitor. Em todas as instruções referentes à ética econômica que passaremos a estudar, depararemos com essa mesma racionalidade.

\section{III. - AS ATITUDES DO BUDISMO FRENTE À RIQUEZA}

$\mathrm{Na}$ tradição monástica e na tradição laica as atitudes frente à riqueza se revelam totalmente diferentes. Na ética monástica prega-se uma atitude de renúncia radical à posse e à acumulação de bens terrenos e à participação do monge em atividades produtivas:

(4). - Citado por NAKAMURA (Hajime), op. cit., p. 84. 
O praticante do Caminho não deve tocar em dinheiro, ouro ou prata, deve viver baseando-se apenas no presente.

(Therigatha 284) (5).

Se algum monge tiver tomado com suas mãos ouro e prata, ou tiver feito alguem tomar por ele, ou tiver entesourado, terá cometido falta.

(Nissaggiya-Pacittiya 18).

Se algum monge se envolver em compra e venda de mercadorias, terá cometido falta.

(Nissagiya-Pacittiya 19).

Os únicos objetos materiais que os monges tem permissão de guardar, e assim mesmo por um período bastante limitado, são os remédios e alimentos destinados aos doentes:

Existem remedios a serem ministrados a monges doentes: manteiga, leite, óleo, mel e ą̧ucar. Quando obtidos, podem ser guardados e usados durante sete dias. Se esse prazo for ultrapassado, será cometida falta.

(Nissaggiya-Pacittiya 23).

Ao monge era vedada toda a participação na agricultura e tarefas afins:

Se um monge escavar a terra ou mandar alguem faze-1o, cometerá falta.

(Nissaggiya-Pacittiya 10).

Cortar plantas e árvores é falta.

(Shibunritsu 12).

Por esses textos é facil perceber como o ideal monástico do Budismo Primitivo estava distante do ora et labora do monasticismo cristão. Cumpre notar, porem, que se essas regras ainda hoje continuam a ser obedecidas pelos monges do Sudeste Asiático, enquanto individuos, poucos séculos depois de Buda elas foram atenuadas para atender as necessidades das grandes comunidades monásticas. Estas, que passaram a receber grandes doações de dinheiro e terras por parte de seus patronos e protetores leigos, tiveram que atenuar as regras para administrar de maneira produtiva esses bens, em seu próprio benefício. Tanto na India, como na China e no Japão, as comunidades monásticas administraram grandes latifúndios cultivados por servos e eventualmente dedicaram-se tambem ao comércio e ao empréstimo

(5). - Este texto e os que se seguem foram traduzidos de NAKAMU. RA (Hajime), op, cit., p. 78 . 
a juros. E importante lembrar que na tradição budista jamais foi enunciada nenhuma proibição em relação à usura, como a que vigorava na Europa medieval. A principal razão que levou as autoridades chinesa a desencadearem uma severa perseguição ao Budismo no século IX foi justamente o enorme acumulo de terras e ouro, nas mãos das comunidades monásticas budistas. Posteriormente, os monges do $\mathrm{Bu}$ dismo Zen da China introduziram em suas regras o trabalho manual, principalmente o agrícola, tradição que ainda hoje é mantida pelo Budismo Zen japonês. Com o Zen, o monasticismo budista se aproximou do ideal de vida preconizado por São Bento, no Ocidente.

Entretanto, o ascetismo monástico não é a única via de realização espiritual proposta pelo Budismo. Não obstante ser a via preferida por certas escolas, coexiste com ela a via laica e, alguns textos afirmam que mais vale um leigo sincero do que um monge negligente:

Ainda que o corpo esteja envolvido por vestes laicas, o espírito pode se elevar até as mais altas perfeiçöes. $O$ homem do mundo e o eremita não diferem nada um do outro se ambos tiverem vencido o egoismo. Enquanto o coração permanecer encadeado pelos laços da sensualidade, toda a aparência exterior de ascetismo näo passa de coisa vã.

(Fo-sho-hing-tsan-king) (6).

Se para o monge o dever é se desapegar totalmente da riqueza, o dos leigos, pelo contrário, é trabalhar diligentemente para acumula-la. A ética destinada aos leigos exalta as virtudes que auxiliam o acumulo da riqueza, como a diligência e a poupança, condenando a preguiça, a prodigalidade e os vícios que provocam o esbanjamento dos bens:

Se alguem, morando em lugar apropriado, se aproximar de uma pessoa nobre e servi-la, sempre guardando intenções corretas e praticando o bem, acumulará alimento, fortuna, honra e paz. (Anguttara Nikaya II) (7).

O' monges, há comerciantes que não se esforçam nem pela manhã, nem pelo meio-dia, nem à tarde. Aqueles que assim fazem não obterão novos bens nem multiplicarão os que já possuem... Há comerciantes que se esforçam pela manhã, pelo meio-dia e pela tarde. Aqueles que assim o fazem obterão novos bens e multiplicarão os que já possuem.

(Anguttara Nikaya $\mathrm{I}$ ).

(6). - Citado por DAVID-NEEL, (Alexandra), op. cit., p. 253, 254.

(7). - Este texto e os que se seguem foram traduzidos de NAKAMURA (Hajime), op. cit., p. 79-82. 
Suponhamos que uma pessoa de boa família tenha bens obtidos com esforço, acumulados com diligência, reunidos com suor, adquiridos corretamente, conforme a Lei. Suponhamos que ela os guarde e entesoure, pensando: Que estes bens não sejam arrebatados pelo rei, roubados por ladrões, queimados pelo fogo, carregados pela água ou levados por herdeiros odiosos.

Isto se chama uma perfeita segurança.

(Anguttara Nikaya IV).

As famílias não permanecem sempre numa mesma situação. Podem ocorrer calamidades devidas ao rei ou a outros fatores. E por isso que se manda poupar uma parte do que se tem, para prevenir tais eventualidades.

(Sumangalavilasini).

O' Brâmanes, há quatro portas pelas quais se escoa a riqueza acumulada: viciar-se em mulheres, viciar-se em bebidas, viciar-se no jogo, possuir maus amigos, maus colegas e maus companheiros... Há quatro portas pelas quais entra a riqueza: não se viciar em mulheres, não se viciar na bebida, não se viciar no jogo, não possuir maus amigos, maus colegas e maus companheiros.

(Anguttara Nikaya IV).

Como se obtem riquezas?

Aquele que age com discernimento e se esforça pacientemen. te obtem riquezas. Com retidão alcança fama e praticando doações cria laços de amizade.

(Suttanipata 187).

Aquele que, tendo se endividado, alega não ter dívida alguma quando o credor lhe cobra, não passa de um vil.

(Suttanipata 120).

Aquele que acumula riquezas misturando processos lícitos e ilícitos, cometendo roubos e fraudes, mentindo à toda hora, mostrando habilidade apenas em empilhar tesouros e que se entrega aos desejos e prazeres, irá para o inferno.

(Anguttara Nikaya I).

Vemos pelas três últimas citações que o Budismo Primitivo exigia dos leigos o mesmo tipo de honradez e honestidade nos negócios preconizado pela ética da burguesia capitalista do mundo ocidental. Os textos seguintes apresentam conselhos ainda mais minuciosos para o sucesso nas atividades econômicas e apresentam as mesmas idéias que se aproximam do moderno conceito de crédito:

Se alguem se aproximar de um Brâmane ou de um asceta, perguntar-lhe o que ele mais deseja e não lhe der a coisa desejada em seguida, morrerá e renascerá como um comerciante que jamais obtem êxito em seus negócios. 
Se alguem se aproximar de um Brâmane ou de um asceta, perguntar-lhe o que ele mais deseja e não the dizer uma dádiva à altura de suas expectativas, em seguida, morrerá e renascerá como um comerciante cujos empreendimentos jamais correspondem às suas expectativas.

Se alguem se aproximar de um Brâmane ou de um asceta, perguntar-lhe o que ele mais deseja e lhe der a coisa desejada em seguida, morrerá e renascerá como um comerciante que sempre obterá o êxito esperado.

Se alguem se aproximar de um Brâmane ou de um asceta, perguntar-lhe o que ele mais deseja e lhe der uma dádiva superior a seus desejos em seguida, morrerá e renascerá como um comerciante cujos êxitos serão superiores a suas expectativas.

(Anguttara Nikaya II).

O' Brâmane, assim como um comerciante ou um empregado do comerciante controla o peso de algo observando o fiel da balança, da mesma forma um homem de boa família leva uma vida controlada, observando a entrada e a saida de recursos, não se deixando cair nem na dissipação extrema nem na privação exagerada. Ele se controla de modo a que lhe reste um saldo do que entrou, após as despesas, de modo que estas não impeçam a conservação de uma reserva.

O' Brâmane, se um homem de boa familia leva uma vida muito opulenta, não obstante suas rendas serem poucas, dirão que ele devora seus bens como quem come o fruto udumbala.

O' Brâmane, se um homem de boa família leva uma vida de pobreza, não obstante suas rendas serem muitas, dirão que ele morrerá como um faminto.

O' Brâmane, é por isso que o homem de boa família, observando a entrada e a saida de recursos, leva uma vida equilibrada, não caindo nem na dissipação extrema nem na privação exagerada.

$O$ comerciante que obedecer às três condições verá em pouco tempo sua fortuna aumentada. Quais são as três condições? $O$ comerciante deve ter discernimento, operar com habilidade e ter sólidas bases.

Ter discernimento significa conhecer a mercadoria: como ela é comprada, como ela é vendida, seu valor e o lucro que propicia.

Operar com habilidade significa ser habil em comprar e vender.

Ter bases sólidas significa ser conhecido pelos comerciantes ricos ou por seus filhos como um comerciante que tem discerni- 
mento, opera com habilidade, sustenta sua família e, quando necessário, tem a capacidade de auxiliar os demais comerciantes. Eles o chamarão e o convidarão para dispor de seus recursos para comprar bens, alimentar a família e auxiliar os demais comerciantes, quando for necessário. Quando isso ocorre, o comerciante tem bases sólidas.

O comerciante que satisfaz a essas três condições aumentará sua fortuna em pouco tempo.

(Anguttara Nikaya I).

Vemos por esses textos quão minuciosas são as instruções do $\mathrm{Bu}-$ dismo Primitivo referentes à acumulação da riqueza. Mas elas não se limitam apenas a isso. Preocupam-se tambem em estabelecer as normas para uma utilização justa da riqueza acumulada. O objetivo da riqueza não é satisfazer os caprichos egoistas de seu dono, mas beneficiar o maior número de pessoas possíveis através de uma distribuição generosa. Dana, o ato de doar bens materiais ou ensinamentos espirituais é uma das práticas virtuosas fundamentais da vida budista, tanto para os monges quanto para os leigos. Em suas preocupações com as justas distribuições das riquezas, a ética econômica budista transcende as preocupações de uma ética de tendências puramente capitalistas, aproximando-se de um ideal socializante.

O ato de doar está intimamente ligada às práticas comum a todas as escolas religiosas da India de se oferecerem alimentos, roupas e outros bens materiais aos ascetas e sábios religiosos, cujo único meio de subsistência está nas contribuições de seus fiéis. $\mathrm{Na}$ ética budista, as doações aos sábios e ascetas tambem ocupam lugar importante, como veremos nos textos que se seguem:

O homem piedoso vive com seu coração purificado da mácula da avareza, dá com boa vontade, tem as mãos puras, alegra-se com a distribuição, é acessivel aos pedidos alheios e se compraz na distribuição equitativa dos bens.

(Anguttara Nikaya $\mathrm{I}$ ).

Aquele que acumu'ou riquezas conforme a Lei é diligente e contenta de modo correto aquele que pede alimento, fornecendo-lhe o desejado.

(Itivuttaka 75 G.).

O sábio piedoso e experiente reserva alimentos para contentar aqueles que os pedirem.

(Samyutta Nikaya I).

Se aquele que possuir uma imensa riqueza, ouro e alimentos, se limitar a saborear seus manjares sozinho, estará nas portas da ruína.

(Suttanipata 104). 
O homem superior é aquele que, distribuindo suas riquezas obtidas conforme a Lei, oferece aos outros o fruto de sua diligência. Aquele que assim procede é o maior dos pensadores, uma pessoa acima de qualquer dúvida. Seu destino é um lugar feliz, onde não terá nenhuma preocupação.

(Anguttara Nikaya I).

Antes de dar o coração se alegra, durante $o$ ato de dar ele se purifica, e depois de dar, ele se sente satisfeito.

(Anguttara Nikaya III).

Alguns dão o pouco que têm, outros, embora ricos, nada dão (Samyutta Nikaya I).

o comerciante, o veneravel discípulo faz quatro coisas com a riqueza que acumulou conforme a Lei, através do esforço, do suor, do trabalho físico. Estas são as quatro coisas:

1). - Alegra-se a si mesmo, alimenta-se, e preserva a sua felicidade. Dá portanto a alegria a sua família, seus servos e empregados, alimenta-os e preserva-lhes a sua felicidade. Dá alegria a seus amigos e companheiros, alimenta-os e preserva-lhes a sua felicidade.

2). - Quando há prejuizos devido ao fogo, à água, ao rei, aos ladrões ou aos herdeiros indesejáveis, faça uso de suas riquezas para preservar-se, mantendo-se em estado de segurança e tranquilidade.

3). - Pratique as cinco ofertas, ou seja, as ofertas aos parentes, aos hóspedes, aos ancestrais, ao rei e aos deuses.

4). - Dê aos ascetas e aos brâmanes ofertas que atraiam o aprimoramento, o renascimento nos mundos celestes, a felicidade e as maravilhas celestiais, caso esses ascetas e Brâmanes estejam livres do orgulho e da indolência por guardarem a humildade e a mansidão $\mathbf{e}$ tambem para controlarem, integrarem e apaziguarem seu eu.

(Anguttara Nikaya II).

Os textos seguintes, ao mesmo tempo que encorajam as doações de bens, advertem contra o apego egoista em relação aos bens materiais:

Um discípulo de Buda, ao perder suas posses, não se lamenta, limitando-se a considerar que suas posses se foram, não obstante ter ele feito tudo o que pudesse se converter em causa da obtenção de riquezas.

(Anguttara Nikaya III).

O' Mahanaman, o veneravel discípulo medita em seu íntimo sobre o despreendimento e disponibilidade de si mesmo, dizendo: Eu tenho lucros, bens que tive sucesso em acumular. Vivo no 
meio de uma multidão maculada pela avareza, mas meu coração está livre dessa mácula. Dou com boa vontade, mantenho minhas mãos puras, alegro-me com a distribuição, sou acessivel aos pedidos alheios, regozijo-me com a repartição de minhas riquezas.

Quando o veneravel discípulo medita sobre o despreendimento e sobre a prodigalidade, seu coração se torna livre do desejo, da cólera e da ignorância. Seu coração se torna puro e correto graças ao ato de dar...... O veneravel discípulo de coração puro e correto se empenha em relação à justiça e à Lei, goza das alegrias obtidas em conformidade com a Lei e esse gozo dá tranquilidade e repouso ao seu corpo, o que lhe propicia a paz que conduz à concentração mental.

(Anguttara Nikaya III).

Um homem, embora receptivo aos desejos, obtem e pratica a Sabedoria que leva à Libertação, se observa o seguinte:

1). - Obter riquezas conforme a Lei, sem recorrer à violência.

2). - Obter riquezas conforme a Lei, sem recorrer à violência, para dar poder e tranquilidade a si próprio.

3). - Distribuir seus bens para criar felicidade.

4). - Não se apegar aos bens, não se perturbar e não cometer faltas por causa dos mesmos.

(Samyutta Nikaya IV).

Os que vivem conforme a Lei, praticam os preceitos, falam a verdade, são comedidos, libertos do mundo da impermanência e castos,.... renascem nos mundos celestiais ou em boas famílias deste, alcançando o Nirvana em seguida.

(Anguttara Nikaya III).

Os textos éticos budistas não se esquecem tambem de fazer sérias advertências aos governantes, no sentido de controlarem suas ambições e caprichos pessoais e de utilizarem a riqueza para promoverem a prosperidade geral em seus estados:

O Senhor Buda disse a um Brâmane conselheiro de um rei o seguinte:

- Outrora o rei Mahavisita decidiu realizar um grande sacrifício religioso, mas o brâmane que era seu conselheiro advertiu-o, dizendo que no reino havia muita matança e pilhagem, e que se o rei se dispuzesse a recolher impostos em tal situação, estaria agindo contra a Lei. Observou tambem que não seria bom tentar eliminar o crime por meio de castigos e propôs o seguinte plano: $O$ rei distribuiria sementes e alimentos aos que se aplicassem à agricultura e à criação, concederia crédito aos que se apli- 
cassem ao comércio, ofereceria alimentos e rendas aos detentores de funções públicas. Se todos assim passassem a se dedicar integralmente às respectivas profissões, não perturbariam o reino $e$ ainda acumulariam grandes riquezas para o rei. $O$ reino ficaria então em tranquilidade e em paz, não haveria dissabores e as pessoas, tomadas de contentamento, fariam dançar suas crianças ao colo, sem sequer preocupar em fechar as portas das casas. Dizem que o rei seguiu os conselhos do Brâmane e que tudo ocorreu conforme este previra.

(Digha-Nikaya I - Kutadanta Suttanta).

\section{IV. - O BUDISMO E O MUNDO COMERCIAL.}

O leitor que leu com atenção os textos éticos apresentados acima deve ter notado que a maior parte dos mesmos se dirige à pessoas vinculadas a atividades mercantis. Isso faz supor que grande parte dos discípulos laicos do Budismo Primitivo era recrutada entre os comerciantes. Essa suposição é amplamente confirmada pelas mais recentes pesquisas referentes à História Antiga da India e às origens do Budismo. D. D. Kosambi realçou o carater progressista e modernizante das idéias econômicas e políticas do Budismo, vinculando-as com a conjuntura da época em que o mesmo surgiu: os séculos VI e V a.C. (8). Essa época se caracterizou por uma série de profundas transformações na sociedade indiana: urbanização, desenvolvimento do comércio, evolução das estruturas tribais rumo à formação de poderosos estados monárquicos. O Prof. Yushô Miyasaka, em seus estudos sobre as origens do Budismo, realçou as profundas relações do mesmo com as sociedades tribais ameaçadas de extinção pelos nascentes estados monárquicos (9). Essas relações explicariam a atitude crítica dos textos budistas em relação aos reis, considerados como fontes de males equiparáveis às calamidades naturais e aos ladrōes, atitude essa que transparece em alguns dos textos que apresentamos acima. Finalmente, em seus minuciosos estudos sobre o background econômico, social e político das origens do Budismo, o Prof. Hajime Nakamura realça a importância dos comerciantes nas novas cidades que floresciam na Bacia do Ganges nessa época. Mostra ele como o desenvolvimento das cidades e dos estados monárquicos foi possivel graças à aliança entre os comerciantes, em pleno desenvolvimento de suas atividades, e a nobreza guerreira, de onde sairam os dirigentes dos novos estados. Essa nova sociedade, centralizada nas cidades, contrastava com as an-

(8). - KOSAMBI (D. D.), Indo Kodaishi (História Antiga da India), Tokyo, Iwanami, 1966, p. 148-174.

(9). - MIYASAKA (Yushô), Bukkyô no Kigen (As Origens do Budismo), Tokyo, Sankibô, 1971. 
tigas sociedades védico-bramânicas, fundamentalmente rurais e lideradas pelos brâmanes ou sacerdotes. O processo de urbanização acarretou uma atitude crítica da nobreza guerreira e dos comerciantes frente ao pensamento Bramânico, que resultou na formação das correntes de pensamento heterodoxas, contestatórias da autoridades absoluta dos Brâmanes. Dentre estas, destaca-se o Budismo, cujo fundador Siddhartha Gautama pertencia à nobreza guerreira e cujos discípulos, em grande parte, foram recrutados entre os prósperos comerciantes das cidades. O Prof. Hajime Nakamura, em seus estudos sobre a vida de Siddhartha Gautama, realça vários episódios que, juntamente com os textos éticos por nós apresentados, atestam as vinculações existentes entre o Budismo Primitivo e os comerciantes. Os primeiros ouvintes da mensagem religiosa de Gautama teriam sido dois comerciantes, Tapassu e Bhallika, que se tornaram os primeiros discípulos laicos de Buda, antes mesmo do famoso sermão do Parque das Gazelas, dirigido aos cinco primeiros discípulos monges (11). Um dos principais protetores de Gautama foi o rico comerciante Sudatta, do reino de Kosala, apelidado Anathapindika (aquele que dá alimentos aos desamparados) por causa de sua generosidade. Sudatta construiu para Gautama um dos primeiros mosteiros budistas, no terreno que adquiriu para esse fim de Jetavana, nos subúrbios de Savatthi, capital de Kosala (12). Uma das últimas viagens de Gautama, antes de sua morte, teve como destino a rica cidade comercial de Vaisali, onde foi recebido com todas as honras (13).

Uma análise da literatura budista posterior mostra que essa associação entre o Budismo e o comércio se manteve através dos séculos. No famoso Saddharma-pundarika-sutra (O Livro do Lótus da Suprema Lei), texto doutrinário que data dos primeiros anos da era cristã, encontramos a célebre Parábola do Filho Perdido, cujo principal personagem é o filho de um rico negociante, cujas riquezas e atividades são descritas minuciosamente (14). O Vimalakirti-Nirdesa, texto apologético do Budismo laico que data aproximadamente da mesma época, tem como protagonista o opulento comerciante Vimalakirti, que excede em virtudes e em sabedoria os discípulos monges de Buda (15).

Essa associação do Budismo com o comércio parece ser responsavel pelo fato de que a ética econômica budista dá muito mais ênfase

(10). - NAKAMURA (Hajime) - Indo Kodaishi (História Antiga da India), 2 v. Tokyo, Shunjusha, $1963,2^{\circ}$ v., p. 171-313.

(11). - NAKAMURA (Hajime), Gauiama Buddha, Tokyo, Shunjusha, 1971, p. 207-211.

(12). - NAKAMURA (Hajime), op. cit., p. 363-382.

(13). - NAKAMURA (Hajime), op. cit., p. 437-442.

(14). - GONÇALVES (R. R. M.), Textos Budistas e Zen Budistas, São Paulo, Cultrix, 1967, p. 90-96.

(15). - GONÇALVES (R. R. M.), op. cit., p. 97-110. 
às atividades que facilitam a circulação das mercadorias (abertura de estradas, construção de pontes e canais, etc.) do que propriamente as atividades produtivas (artezanato e agricultura). Essa tradição de apôio e estímulo às atividades comerciais parece ainda ser uma importante fonte da ética econômica racionalizante e modernizante que encontramos nos escritores japoneses do Período Tokugawa, a que nos referimos na introdução.

\section{CONCLUSÃO.}

Os pesquisadores japoneses, como os Profs. Hajime Nakamura e Yushô Miyasaka têm comparado a ética econômica do Budismo Primitivo e seus desenvolvimentos posteriores com a ética do Protestantismo, tal como foi estudada por Max Weber em seu famoso estudo $A$ Etica Protestante e o Espirito do Capitalismo. Essa comparação não deixa de ser fecunda, mas é necessário notar que existe uma diferença fundamental entre a ética protestante e a budista. Como o próprio Max Weber salientou em seu estudo, as prováveis influências da ética protestante sobre a consolidação do espírito do capitalismo foram de natureza indireta. Nada estava mais longe da intenção dos reformadores do Cristianismo do que o estímulo ao desenvolvimento das atividades mercantis. $\mathrm{O}$ que eles queriam era substituir o ascetismo monástico por um novo ascetismo intramundano, em que uma vida severa e frugal, dedicada exclusivamente às atividades profissionais seria uma forma de agradar e servir a Deus de maneira mais válida do que as austeridades do claustro. $O$ espírito de poupança e de dedicação ao trabalho que se desenvolveu como consequência dessa posição dos reformadores e que teriam contribuido para desenvolver ou consolidar o espírito do Capitalismo não seria senão uma consequência indireta e secundária que provavelmente teria surpreendido os próprios reformadores. Na ética budista, pelo contrário, notamos uma preocupação consciente com as atividades comerciais e instruções bem claras sobre os meios de se acumular a riqueza e de se dispor da mesma. A mesma atitude é encontrada nos escritores japoneses do período Tokugawa e nos líderes da Restauração Meiji. As motivaçães de ordem ética à modernização e ao desenvolvimento do Capitalismo que podem ter atuado no processo de modernização do Japão não foram de natureza indireta, como no Ocidente, mas de ordem consciente e direta .

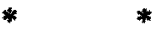


RICARDO MÁRIO GONÇALVES. - Professor Assistente-Doutor da Faculdade de Filosofia, Letras e Ciências Humanas da Universidade de São Paulo.

Especialista em História Asiática e Africana.

Duas viagens de estudos ao Japão (1968 e 1972-73).

Principais publicações:

Textos Budistas e Zen-Budistas, São Paulo, Cultrix, 1967.

Tannishô - O Tratado de Lamentação das Heresias, São Paulo, Templo Higashi Honganji, 1974.

Consideraçōes sobre o Culto de Amida no Japão Medieval, São Paulo, Coleção da Revista de História n LX, 1975. (Tese de Doutoramento defendida na Universidade de São Paulo em dezembro de 1971). 